Tohoku J. exp. Med., 1972, 108, 283-289

\title{
Mechanical Responses of the Isolated Rabbit Testis to Electrical Stimulation and to Autonomic Drugs
}

\author{
Akira Rikimaru and Taizo Suzuki \\ Department of Applied Physiology, Tohoku University School of \\ Medicine, Sendai
}

\begin{abstract}
Rikmaro, A. and Suzokr, T. Mechanical Responses of the lsolated Rabbit Testis to Electrical Stimulation and to Autonomic Drugs. Tohoku J. exp. Med., $1972,108(3), 283-289$ — The Isolated testicular preparation of rabbit responded to acetylcholine, noradrenaline, adrenaline and isoproterenol with contractions or relaxations. Cholinergic and adrenergic receptor blocking agents revealed the presence of musearinic receptors, and adrenergic $\alpha$ - and $\beta$-receptors in this preparation. Field stimulation with A.C. $(3 \mathrm{~V} / \mathrm{cm}, 50 \mathrm{~Hz})$ or DMPP, elicited contractions which are susceptible to bretylium but to neither hexamethonium nor atropine. These results may rather be taken as evidence for the presence of adrenergic innervation to the rabbit testis. The testicular preparation showed slow spontaneous rhythmic contractions. These spontaneous contractions as well as the contractions elicited by field stimulation were entirely abolished by manganese ion. However, these contractions were resistant to TTX, and were little influenced even by removal of the parenchymal tissues from the capsule. These results may imply the possible presence of smooth muscle cells or other contractile tissues resembling smooth muscle cells within the testicular capsule. _ rabbit testis; contraction; relaxation; electrical stimulation; autonomic drugs
\end{abstract}

The mechanism of the transport of non-motile spermatozoa from the seminiferous tubules of the testis to the epididymis has long been a matter of question. Recently Davis and Langford $(1969,1970)$ reported that the capsule of rat testis was capable of responding to acetylcholine, sympathomimetic amines and other autonomic drugs. Their observations raised some important question whether the contraction of the testicular capsule plays an indispensable role in the transport of spermatozoa from the seminiferous tubules to the epididymis.

The aim of the present paper has been to extend the observations of Davis and Langford $(1969,1970)$ to other testicular preparation. The mechanical responses of the isolated rabbit testis to electrical stimulation and to autonomic drugs were investigated.

\section{Materials and Methods}

Male rabbits, weighing between 2.2 and $2.4 \mathrm{~kg}$, were used. After the animal was killed by a head blow, the testis was removed and the epididymis was carefully dissected away from the testis. Then the testis was eut into two pieces by a longitudinal section

Received for publication, April 5, 1972. 
and one of them was tied with cotton threads to mount in an organ bath filled with $40 \mathrm{ml}$ of modified Krebs' solution ( $\mathrm{NaCl} 120.9, \mathrm{KCl} 5.9, \mathrm{CaCl}_{2} 2.5, \mathrm{MgCl}_{2} 1.2, \mathrm{NaHCO}_{3} 15.5$, $\mathrm{NaH}_{2} \mathrm{PO}_{4} 1.2$ and glucose $11.5 \mathrm{mM}$ ). This solution was bubbled with $95 \% \mathrm{O}_{2}$ and $5 \%$ $\mathrm{CO}_{2}$ and the temperature was kept at $37^{\circ} \mathrm{C}$.

Field stimulation with A.C. $(50 \mathrm{~Hz})$ was applied for five seconds through $\mathrm{Ag}-\mathrm{AgCl}$ plate electrodes placed at both ends of the bath. The tension change of the testicular preparation was recorded isometrically with a strain-gauge transducer (Grass FT-03) and an ink-writing oscillograph (Grass Model-5 Polygraph).

The drugs used are: dimethyl-4-phenylpiperazium iodide (DMPP), tetrodotoxin, atropine sulfate, physostigmine sulfate, bretylium tosylate, tyramine hydrochloride, hexamethonium bromide, acetylcholine chloride, noradrenaline hydrochloride, adrenaline hydrochloride, isoproterenol hydroohloride, phentolamine hydrochloride, phenoxybenzamine hydrochloride and propranolol hydrochloride. The doses were given in terms of the salt $(\mathrm{g} / \mathrm{ml})$.

\section{Results}

Responses to sympathomimetic amines and effects of adrenoceptor blocking agents

As shown in Fig. 1, noradrenaline and adrenaline produced contractions of the testicular preparation. The minimum concentrations of these agents to produce contractions were usually between $10^{-9}$ and $10^{-8} \mathrm{~g} / \mathrm{ml}$, and the maximal responses were reached at $10^{-6} \mathrm{~g} / \mathrm{ml}$ (Fig. 2). The contraction produced by noradrenaline was usually slightly larger than that produced by adrenaline. Isoproterenol, on
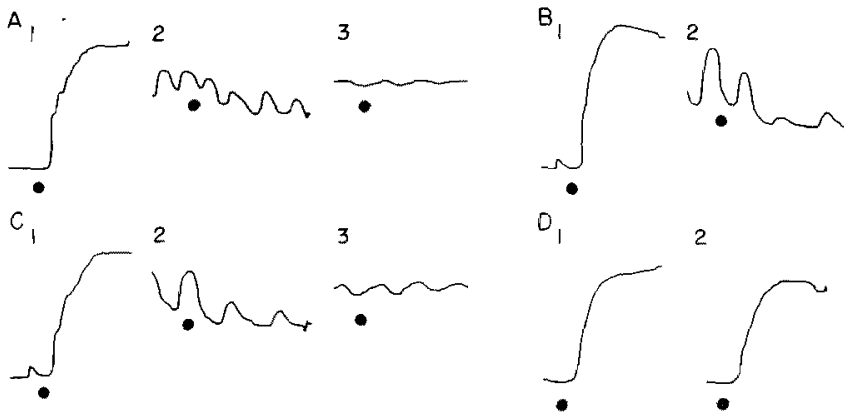

3
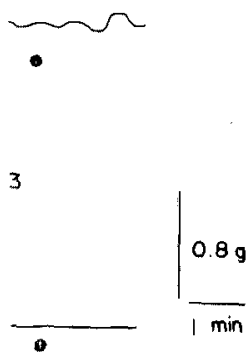

Fig. 1. Responses to sympathomimetic amines and to acetylcholine.

$A, B$ and $C$, responses to noradrenaline $\left(10^{-6} \mathrm{~g} / \mathrm{ml}\right)$, adrenaline $\left(10^{-6} \mathrm{~g} / \mathrm{ml}\right)$ and isoproterenol $\left(10^{-8} \mathrm{~g} / \mathrm{ml}\right)$, respectively. 1 , control; 2 , in presence of phentolamine $\left(10^{-6}\right.$ $\mathrm{g} / \mathrm{mg}) ; 3$, in presence of phentolamine $\left(10^{-8} \mathrm{~g} / \mathrm{ml}\right)$ and propranolol $\left(10^{-6} \mathrm{~g} / \mathrm{ml}\right)$. D, response to acetylcholine $\left(10^{-\beta} \mathrm{g} / \mathrm{ml}\right)$. 1, control; 2 , in presence of hexamethonium $\left(10^{-4} \mathrm{~g} / \mathrm{ml}\right) ; 3$, in presence of atropine $\left(10^{-7} \mathrm{~g} / \mathrm{ml}\right)$. Sympathomimetic amines and acetylcholine were added at the dots.

the other hand, mostly produced relaxation of the testicular preparation, though sometimes produced contraction.

The contractions produced by these sympathomimetic amines were easily reversed to relaxations after addition of a-adrenoceptor blocking agents, phentolamine $\left(10^{-6} \mathrm{~g} / \mathrm{ml}\right)$ or phenoxybenzamine $\left(10^{-6} \mathrm{~g} / \mathrm{ml}\right)$. The relaxations observed after the $\alpha$-blocking agents were entirely prevented by a $\beta$-adrenoceptor blocking 


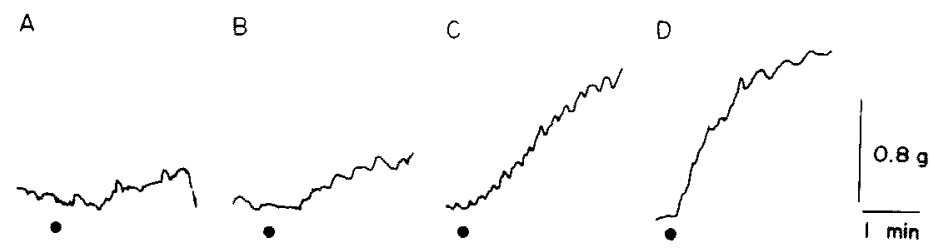

Fig. 2. Response to noradrenaline. The minimal response was produced by noradrenaline at concentration of $10^{-8} \mathrm{~g} / \mathrm{ml}(\mathrm{A})$, and the maximal response at concentration of $10^{-6}$ $\mathrm{g} / \mathrm{ml}(\mathrm{D})$. $\mathrm{B}, 10^{-8} \mathrm{~g} / \mathrm{ml} ; \mathrm{C}, 10^{-7} \mathrm{~g} / \mathrm{ml}$. Noradrenaline was added at the dots.

agent, propranolol $\left(10^{-6} \mathrm{~g} / \mathrm{ml}\right)$. These results strongly indicate the existance of adrenergic $\alpha$ - and $\beta$-receptors in the testicular preparation.

Response to acetylcholine and effects of atropine and hexamethonium

Acetylcholine $\left(10^{-9}-10^{-6} \mathrm{~g} / \mathrm{ml}\right)$ produced contraction of the testicular preparation. This contraction was usually smaller than that produced by noradrenaline. In the presence of atropine $\left(10^{-7} \mathrm{~g} / \mathrm{ml}\right)$, acetylcholine failed to produce contraction of the testicular preparation even at the concentration of $10^{-5} \mathrm{~g} / \mathrm{ml}$. However, hexamethonium $\left(10^{-4} \mathrm{~g} / \mathrm{ml}\right)$ had no influence on the response to acetylcholine (Fig. 1). These results may imply that the cholinergic receptors in the testicular preparation are muscarinic in nature.

Response to DMPP and effects of hexamethonium, atropine and bretylium

DMPP $\left(5 \times 10^{-6}-5 \times 10^{-5} \mathrm{~g} / \mathrm{ml}\right)$, produced contraction of the testicular preparation. This contraction was resistant to the blockade of hexamethonium in the concentration range up to $10^{-4} \mathrm{~g} / \mathrm{ml}$. Futhermore, this contraction was not reduced by atropine $\left(10^{-6} \mathrm{~g} / \mathrm{ml}\right)$, though this concentration of atropine thoroughly prevented the response to acetylcholine $\left(10^{-5} \mathrm{~g} / \mathrm{ml}\right)$. However, bretylium $\left(10^{-5} \mathrm{~g} / \mathrm{ml}\right)$ entirely

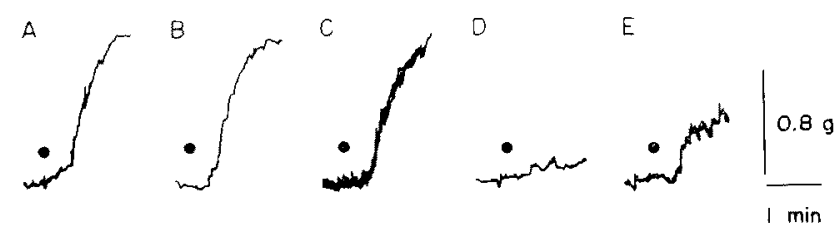

Fig. 3. Response to DMPP. A, control; B, in presence of hexamethonium $\left(10^{-4} \mathrm{~g} / \mathrm{ml}\right) ; \mathrm{C}$, in presence of atropine $\left(10^{-\theta} \mathrm{g} / \mathrm{ml}\right) ; \mathrm{D}$, in presence of bretylium $\left(10^{-5} \mathrm{~g} / \mathrm{ml}\right) ; \mathrm{E}$, after washing bretylium out of the bath and addition of tyramine $\left(10^{-5} \mathrm{~g} / \mathrm{ml}\right)$ into the bath. DMPP was added at the dots.

abolished the contractile response of the testicular preparation to DMPP (Fig. 3). After washing bretylium out of the bath, the contractile response gradually recovered by addition of tyramine $\left(10^{-5} \mathrm{~g} / \mathrm{ml}\right)$ into the bath. These results may be taken as evidence for the existance of adrenergic nerves in this preparation. 
Response to field stimulation with A.C.

Field stimulation with A.C. $(50 \mathrm{~Hz})$ applied to the testicular preparation elicited contraction. Minimal response was usually produced by stimulation at $0.5-0.8 \mathrm{~V} / \mathrm{cm}$, and the maximal response at $3-4 \mathrm{~V} / \mathrm{cm}$. The contraction elicited by field stimulation was neither potentiated by physostigmine $\left(5 \times 10^{-7}-5 \times 10^{-6} \mathrm{~g} / \mathrm{ml}\right)$ nor reduced by atropine $\left(10^{-7}-10^{-6} \mathrm{~g} / \mathrm{ml}\right)$ (Fig. 4). However, the response was reduced by bretylium $\left(10^{-5} \mathrm{~g} / \mathrm{ml}\right)$, (Fig. 5). Furthermore, tetrodotoxin $\left(10^{-8} \mathrm{~g} / \mathrm{ml}\right)$

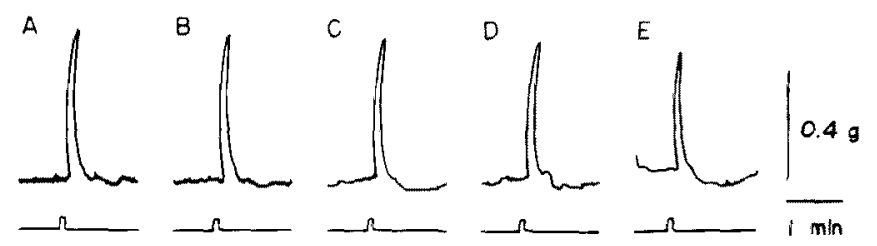

Fig. 4. Contractile response to field stimulation with A.C. $(50 \mathrm{~Hz}, 3 \mathrm{~V} / \mathrm{cm}, 5 \mathrm{sec})$. A, control; $\mathrm{B}$, in presence of physostigmine $\left(5 \times 10^{-6} \mathrm{~g} / \mathrm{ml}\right) ; \mathrm{C}$, in presence of atropine $\left(10^{-6} \mathrm{~g} / \mathrm{ml}\right)$; $\mathrm{D}$, in presence of hexamethonium $\left(10^{-4} \mathrm{~g} / \mathrm{ml}\right) ; \mathrm{E}$, in presence of tetrodotoxin $\left(10^{-8} \mathrm{~g} / \mathrm{ml}\right)$. Lower traces indicate the duration of stimulation.

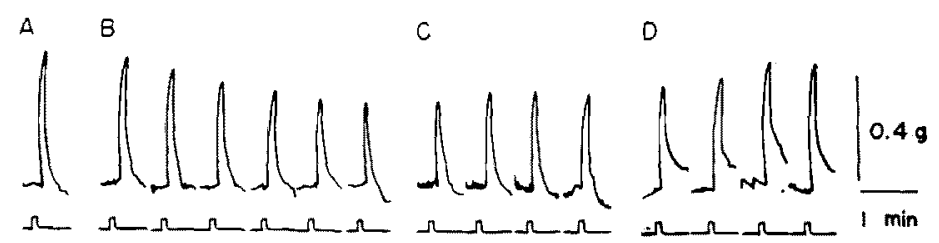

Fig. 5. Contractile response to field stimulation with A.C. $(50 \mathrm{~Hz}, 3 \mathrm{~V} / \mathrm{cm}, 5 \mathrm{sec})$. A, control; $\mathrm{B}$, in presence of bretylium $\left(10^{-5} \mathrm{~g} / \mathrm{ml}\right)$; $\mathrm{C}$, after washing bretylium out of the bath and addition of tyramine into the bath $\left(10^{-5} \mathrm{~g} / \mathrm{ml}\right)$. Lower traces indicate the duration of stimulation.

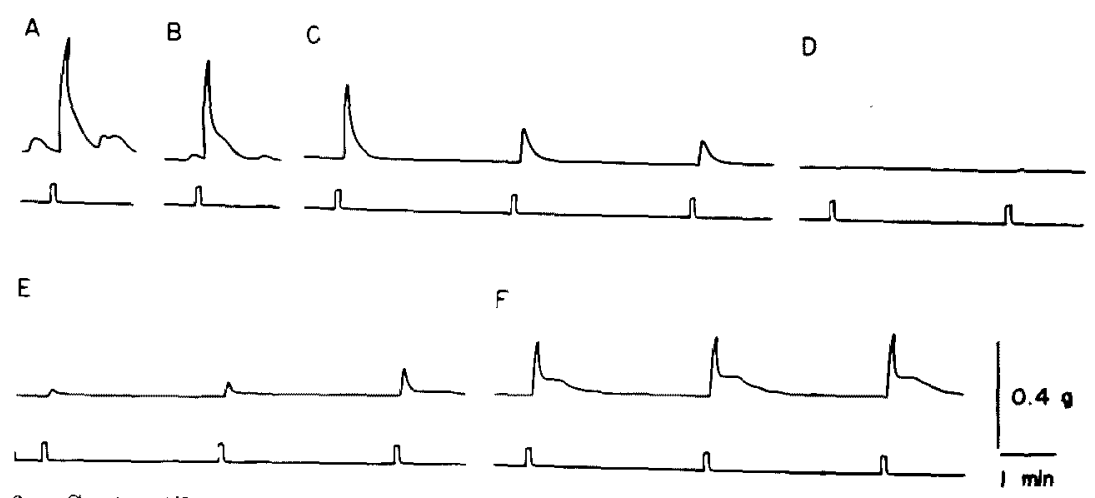

Fig. 6. Contractile response to field stimulation with A.C. $(50 \mathrm{~Hz}, 3 \mathrm{~V} / \mathrm{cm}, 5 \mathrm{sec})$ and the effects of tetrodotoxin and manganese ion. A, control; $\mathrm{B}$, in presence of tetrodotoxin $\left(10^{-7} \mathrm{~g} / \mathrm{ml}\right) ; \mathrm{C}$ and $\mathrm{D}, 5$ and $15 \mathrm{~min}$ after addition of the manganese ion $(1 \mathrm{mM}) ; \mathrm{E}$ and $\mathrm{F}, 5$ and $20 \mathrm{~min}$ after washing manganese ion. Lower traces indicate the duration of
stimulation. 
reduced the contractile response of the testicular preparation to field stimulation, though the toxin never absolished it. The response, which remained after tetrodotoxin, was entirely abolished by manganese ion ( $1 \mathrm{mM}$ ) (Fig. 6).

\section{Spontaneous movements of the testicular preparations}

The testicular preparation showed spontaneous contractions. The frequency of these movements were usually 1 to 5 per minute. The contractions were not abolished by atropine $\left(10^{-7}-10^{-6} \mathrm{~g} / \mathrm{ml}\right)$, bretylium $\left(10^{-5}-5 \times 10^{-5} \mathrm{~g} / \mathrm{ml}\right)$ or

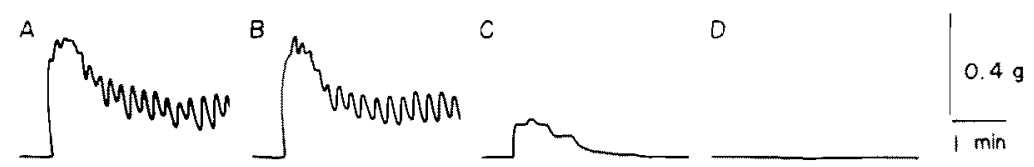

Fig. 7. Spontaneous contraction and the effects of tetrodotoxin and manganese ion. A, control; $\mathrm{B}$, in presence of tetrodotoxin $\left(5 \times 10^{-7} \mathrm{~g} / \mathrm{ml}\right) ; \mathrm{C}$ and $\mathrm{D}, 5$ and $20 \mathrm{~min}$ after addition of manganese ion ( $1 \mathrm{mM}$ ).

tetrodotoxin $\left(10^{-9}-10^{-7} \mathrm{~g} / \mathrm{ml}\right)$. However, manganese ion $(1 \mathrm{mM})$ entirely abolished the spontaneous contractions of the testicular preparation (Fig. 7).

Response to electrical stimulation and to autonomic drugs after removal of the parenchymal tissues from the capsule

In order to determine the main contractile element of the testicular preparation, the responses to field stimulation with A.C. $(3 \mathrm{~V} / \mathrm{cm}, 50 \mathrm{~Hz})$ were compared before and after the removal of the seminiferous tubules and the vasculatures from the capsule. As shown in Fig. 8, the amplitudes of contractions were little
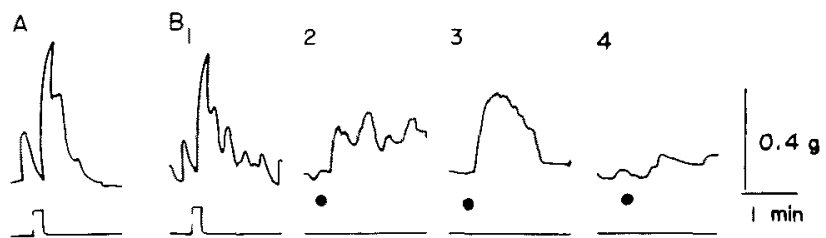

Fig. 8. Responses of the testicular preparation before and after removal of the parenchymal tissues. A, response to field stimulation with A.C. $(50 \mathrm{~Hz}, 3 \mathrm{~V} / \mathrm{cm}, 5 \mathrm{sec})$ before removal; $\mathrm{B}$, responses after removal. 1 , response to field stimulation; 2 , acetylcholine $\left(10^{-6} \mathrm{~g} / \mathrm{ml}\right)$; 3, noradrenaline $\left(10^{-6} \mathrm{~g} / \mathrm{ml}\right) ; 4$, DMPP $\left(5 \times 10^{-5} \mathrm{~g} / \mathrm{ml}\right)$.

influenced by this procedure. Furthermore, noradrenaline $\left(10^{-6} \mathrm{~g} / \mathrm{ml}\right)$ and acetylcholine $\left(10^{-6} \mathrm{~g} / \mathrm{ml}\right)$ also produced contractions of the capsule, though the response to DMPP $\left(5 \times 10^{-5} \mathrm{~g} / \mathrm{ml}\right)$ was less dominant than before the removal of the parenchymal tissues. These results may suggest that the main contractile elemeni of the rabbit testicular preparation is the capsule itself. 


\section{Discussion}

The isolated testicular preparation of rabbit responded to acetylcholine and sympathomimetic amines with contractions or relaxations. The results with cholinergic and adrenergic blocking agents revealed the presence of muscarinic receptors, adrenergic $\alpha$ - and $\beta$-receptors in this preparation. Stimulation of the muscarinic receptors and of $\alpha$-receptors resulted in contractions, whereas that of $\beta$-receptors in relaxations. Futhermore, field stimulation with A.C. also elicited contraction of the testicular preparation.

The testicular preparation used in this experiment was composed of the capsule and the parenchymal tissues. Rich vasculatures were observed in the innermost layer of the capsule. The responses of the testicular preparation may, therefore, be due to stimulation of 1) the capsule, 2) the parenchymal tissues, especially the seminiferous tubules, or 3 ) the blood vessels. Then the seminiferous tubules and the blood vessels were gently teased away from the capsule. It was found that this procedure scarcely influenced the contractile responses of the testicular preparation to electrical stimulation and to autonomic drugs. Thus the possibility of 2) and 3) were ruled out. Though there is evidence suggesting the existance of smooth muscle cell-like structures in the wall of the seminiferous (Clermont 1958, Lancy and Rotblat 1960, Lancy 1962, Leeson and Leeson 1963, Kagayama et al. 1965), the seminiferous tubules made little contribution to the responses of the testicular preparation, nor did the vasculatures. It is concluded from these results that the main contractile element of the testicular preparation is the capsule itself.

The testicular preparation of rabbit not only responded to autonomic drugs and to electrical stimulation but also showed spontaneous rhythmic contractions. The spontaneous contractions and the responses induced by autonomic drugs or electrical stimulation were resistant to tetrodotoxin but easily abolished by manganese ion. These results are quite similar to those of smooth muscle tissues (Nonomura et al. 1966, Kuribayashi 1969 a, b). However, the testicular capsule, which is the main contractile element of the testicular preparation, has long been believed to be composed of only the connective tissues and apparently lacking the smooth muscle cells (see for example Rolshoven 1936). The observation of Majno et al. (1971) is of special interest in this respect. They observed that the strips of granulation tissue experimentally produced in rat contracted with some autonomic drugs, and concluded that the fibroblasts are capable of modulating toward a cell type that is structurally and functionally close to smooth muscle cell under certain conditions. Then the response of the testicular preparation to electrical stimulation and to autonomic drugs may also be due to stimulation of such kind of fibroblasts. Histological re-investigation is quite necessary to determine whether the testicular capsule is composed of only the connective tissues and devoid of the smooth muscle cells.

Davis and Langford (1970) observed that tetramethyl-ammonium produced contraction of the rat testicular capsule and suggested the presence of parasympa- 
thetic ganglia within it. In the rabbit testicular preparation contraction was also elicited by DMPP, a ganglion stimulant. However, this contraction was not abolished by the ganglion blocking agent. Moreover the response to DMPP was not antagonized by blockers of the muscarinic receptors but easily abolished by adrenergic neuron blocking agents. In addition, the contraction elicited by field stimulation with A.C. was also reduced by bretylium or guanethidine, though not influenced by physostigmine or atropine. These results may rather be taken as evidence for the presence of adrenergic innervation in the rabbit testicular preparation.

In conclusion, the isolated rabbit testis apparently responded to electrical stimulation, and to acetylcholine and sympathomimetic amines. The component which mainly contributes to these responses is the capsule itself. The spontaneous contractions and the contractions induced by excitation of the sympathetic adrenergic nerves may provide some propelling force in the transport of nonmotile spermatozoa from the seminiferous tubules to the epididymis as suggested by Davis and Langford (1970).

\section{References}

1) Clermont, Y. (1958) Contractile elements in the limiting membrane of the seminiferous tubules of the rat. Exp. Cell Res., 15, 438-440.

2) Davis, J.R. \& Langford, G.A. (1969) Response of the testicular eapsule to acetylcholine and noradrenaline. Nature (Lond.), 222, 386-387.

3) Davis, J.R. \& Langford, G.A. (1970) Response of the isolated testicular capsule of the rat to autonomic drugs. J. Reprod. Fertil., 19, 595-598.

4) Kagayama, M., Irisawa, S., Shirai, M. \& Matsushita, K. (1965) Contractile cells in the boundary tissue of seminiferous tubules. Jap. J. Urol. (Jap.), 56, 842-847.

5) Kuribayashi, R. (1969 a) Effects of $\mathrm{Mn}$ and $\mathrm{Zn}$ ions on the contraction of smooth muscle of guinea-pig taenia coli. Tohoku J. exp. Med., 98, 231-247.

6) Kuribayashi, R. (1969 b) Effects of $\mathrm{Mn}, \mathrm{Zn}$ and $\mathrm{Mg}$ ions on the electrical activities of smooth muscle of guinea-pig taenia coli. Thohoku J. exp. Med., 98, 249-257.

7) Lancy, D. (1962) Certain aspects of testis structure and function. Brit. med. Bull., 18, 205-208.

8) Laney, D. \& Rotblat, J. (1960) Study of normal and irradiated boundary tissue of the seminiferous tubules of the rat. Exp. Cell Res., 21, 49-70.

9) Leeson, C.R. \& Leeson, T.S. (1963) The postnatal development and differentiation of the boundary tissue of the seminiferous tubule of the rat. Anat. Rec., 147, 243-249.

10) Majno, G., Gabbiani, G., Hirshel, B.J., Ryan, G.B. \& Statkov, P.R. (1971) Contraction of granulation tissue in vitro; similarity to smooth muscle. Science, 173, 548-550.

11) Nonomura, Y., Hotta, Y. \& Ohashi, H. (1966) Tetrodotoxin and manganese ions: Effect on electrical activity and tension in taenia coli of guinea-pig. Science, 152, 97-98.

12) Rolshoven, E. (1936) Ursachen und Bedeutung der intratubulären Sekretströmmung in Säugerhoden. Z. Anat. Entwickl.Gesch., 105, 374-408. 